\title{
Charles Masson and the Buddhist Sites of Afghanistan: Explorations, Excavations, Collections 1832-1835
}

\section{Kurt Behrendt}

To cite this article: Kurt Behrendt (2018): Charles Masson and the Buddhist Sites of Afghanistan: Explorations, Excavations, Collections 1832-1835, South Asian Studies, DOI: 10.1080/02666030.2018.1524200

To link to this article: https://doi.org/10.1080/02666030.2018.1524200

曲 Published online: 10 Oct 2018.

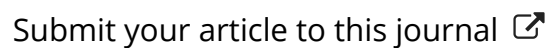

View Crossmark data $\$ 


\section{Book Review}

Elizabeth Errington, Charles Masson and the Buddhist Sites of Afghanistan: Explorations, Excavations, Collections 1832-1835, 2017, 247 pp., £ 40, The British Museum, London

In this ground-breaking volume, Elizabeth Errington, with the help of a group of dedicated collaborators who include Piers Baker, Kirstin Leighton-Boyce, and Wannaporn Rienjang, has been able to assemble and publish many of the finds gathered in south-east Afghanistan by Charles Masson between 1833 and 1838, which today are kept in the British Museum. While Masson had a notable understanding of the Afghan numismatic tradition and made astonishing archaeological contributions for his time in a book called Ariana Antiqua, ${ }^{1}$ published in 1841, his interpretations are understandably dated and only a fraction of his finds were described. Fortunately, his extensive official and private correspondence held in the India Office Collection of the British Library, together with many maps and drawings of key objects, allowed Errington to track down and identify a huge corpus of reliquaries, coins, beads, and associated material remains. Moreover, his documentation provided a credible foundation to link these finds to specific Buddhist sites that Masson surveyed around Kabul, Jalalabad, and Wardak. The accuracy of this correlation is striking, and in many instances, Errington has been able to juxtapose Masson's site elevations with photographs, giving the reader a sense for the preservation of these Buddhist centres and how this has changed since the mid-nineteenth century. The selection of objects included in this volume are complemented by a great many other finds published online in The Charles Masson Archive: British Library and British Museum Documents Relating to the 1832-1838 Masson Collection from Afghanistan (British Museum Research Publication number 216). It is important to note that a large group of coins and other material that Masson recovered from the urban site of Begram still await publication.

Charles Masson (1800-53) found himself in Afghanistan after deserting from the British army in 1827. Using his accounts and a variety of other sources, Errington is able to trace Masson's actions and to explore some of the reasons he came to excavate in Afghanistan in a period that essentially predates the modern discipline of archaeology. It was at this time that amateur treasure hunters in the Gandharan region of Pakistan realized that the relic deposits often contained coins showing connections to the Greek and Roman world. Masson took this knowledge to Afghanistan where he too opened stupas. The only difference is that he carefully documented his activities. In addition to recording his finds, he mapped the sites and produced numerous drawings of the sites and the things he recovered. The British East India company employed and funded Masson's fieldwork between 1832 and 1838 . They eventually came to know his identity as a deserter, and to some extant, others took credit for some of his discoveries; ultimately, he was even compelled to act as a spy. The terms of his employment meant that his finds went to the India Museum in London, and after his death, when this museum was dissolved in 1878, the Masson material was largely transferred to the British Museum.

The success of this volume is the result of many years of research and what can only be described as a herculean effort on Errington's part to make sense of the vast assemblage of material that Charles Masson collected. This endeavour simply would not have been possible if it were not for Errington's deep knowledge of nineteenth-century primary sources associated with the British discovery and excavation of sites related to Gandharan Buddhism in Pakistan and Afghanistan, which was the topic of her 1987 London University dissertation. ${ }^{2}$ While this gave her unprecedented access to nineteenth-century sources, it was her many years of work as a curator in the British Museum's Coins and Medals department that provided her with invaluable expertise in the complex numismatic traditions of this region. For Masson, the site documentation was to give context to the numismatic evidence he was recovering from relic deposits. While Masson can be credited with laying the foundations for the study of this regional numismatic tradition, more than 150 years of subsequent scholarship on this topic, coupled with Errington's expertise, has allowed her to reattribute many of these coins and to correct his early conclusions. More importantly, because Masson catalogued the associated reliquaries, beads, and other finds so carefully, Errington is able to present these objects within a clear chronological and regional framework grounded in the numismatic tradition. This remarkable achievement will 
in coming years undoubtedly fundamentally reshape our understanding of the early Afghan Buddhist tradition. Moreover, this data holds important clues to how Eastern Afghanistan interacted with the ancient regions of Gandhara and Taxila as well as the many Buddhist centres in the Swat Valley, all of which sit just beyond the Khyber Pass in northern Pakistan.

Since the time of Masson in the early nineteenth century, the study of Afghanistan's cultural heritage has been extremely challenging, given the many terrible wars fought in this region. In this light, Errington's re-examination of the Masson archives and finds is extremely important as it documents the foundation deposits when relics were first established at Buddhist sites across south-eastern Afghanistan. The fact that Masson systematically focused on recovering core relic deposits of the major stupas at a time when these monuments were otherwise undisturbed has resulted in a body of evidence that has no comparable parallel in South Asia. At each of these sites, Errington is able to reconstruct and provide photographic documentation of what was found. While the coins tell us a great deal about when Buddhism came to Afghanistan, the many other remains offer insight into this very early Buddhist tradition that largely dates to the first centuries CE. It is important to recognize that Masson focuses on the primary relic deposits and, typically, these central main stupas were refurbished, enlarged, and transformed over the lifetime of the sites' occupation. While the Masson finds primarily tell us about the foundation of the Afghan Buddhist tradition, much of the subsequent archaeological work has focused on later periods. Sites like Hadda, Tepe Sardar, Guldara, Fondukistan, and the massive complexes of Mes Aynak and Bamiyan, excavated and surveyed by French, Italian, Japanese, and Afghan archaeologists, have in contrast uncovered sculptural and archaeological evidence that largely dates to the late phases of occupation at these sites. Much of the recovered sculpture belong to the fourth and fifth centuries, with some remains likely dating to the sixth and seventh centuries. While our understanding of the Buddhist tradition in Afghanistan remains clouded, Elizabeth Errington's reinterpretation and publication of the Masson finds is a major contribution as so much of this material belongs to the early part of this great tradition.

This publication intersects and contributes to a number of research areas that are currently the focus of considerable scholarly activity. Foremost is the massive efforts under way to read and interpret the many Buddhist text fragments written on birch bark that largely appear to come from Afghanistan, with numerous publications resulting from teams of scholars working at both the University of Washington and the University of Munich (see online Bibliography of Gandhari Studies). ${ }^{3}$ While the dating and place of recovery of some of these texts remains debated or unknown, without question many were written in the period under consideration in Errington's study. As this material is reshaping our understanding of early Buddhism, Masson's dated and site-specific finds need to be considered in light of this new textual data. Relics and reliquaries have also been the focus of numerous recent publications, including a 2016 Cambridge University dissertation by Wannaporn Rienjang, ${ }^{4}$ who has also contributed to this volume; also deserving note is a chronological study of inscriptions on reliquaries by Stefan Baums. ${ }^{5}$ This publication offers, for the first time, access to Masson's finds in the form of beautiful photographs and clearly vetted documentation. A body of evidence with far-reaching implications that now is accessible to the broader scholarly community.

\section{NOTES}

1. H. Wilson, Ariana Antiqua: A Descriptive Account of the Antiquities and Coins of Afghanistan with a Memoir on the Buildings Called Topes by C. Masson (London, 1841).

2. Elizabeth Errington, 'The Western Discovery of the Art of Gandhara and the Finds of Jamalgarhi' (PhD thesis, London University, 1987)

3. Stefan Baums and Andrew Glass, 'Bibliography of Gāndhārī Studies' https://www.gandhari.org/a_bib liography.php [accessed 25 August 2018]

4. Wannaporn Rienjang, 'Honouring the Body: Relic Cult Practice in Eastern Afghanistan with Comparison to Dharmarajika Pakistan' (PhD thesis University of Cambridge, 2016).

5. S. Baums, 'A Framework for Gandhāran Chronology Based on Relic Inscriptions', in Problems of Chronology in Gandhāran Art: Proceedings of the First International $W$ orkshop of the Gandhära Connections Project, University of Oxford, $23-24$ March 2017, ed. by W. Rienjang and P. Stewart (Oxford: Archaeopress, 2018), pp.53-70.

Kurt Behrendt The Metropolitan Museum of Art kurt.behrendt@metmuseum.org (C) 2018, Kurt Behrendt https://doi.org/10.1080/02666030.2018.1524200 